\title{
Superparasitism on the Wasp Ammophila pictipennis Walsh (Hymenoptera: Sphecidae: Ammophilinae) by Strepsiptera, with a Record of Observed Instances of Stylopization of Wasps in the Genus Ammophila Kirby from the Grounds of North High School, Sioux City, Iowa, U.S.A. 2008 - $2019^{1}$
}

\author{
G. K. Lechner ${ }^{2}$
}

\begin{abstract}
Stylopization, or parasitism by species of the insect order Strepsiptera, is documented in two species of the sphecid wasp, Ammophila, including, A. fernaldi (Murray, 1938) and A. pictipennis Walsh, 1869. A case of superparasitism by six strepsipterans in one $A$. pictipennis wasp and a neotenous strepsipteran are documented.
\end{abstract}

Key Words: Superparasitism, stylopization, Strepsiptera, Ammophila cleopatra, A. fernaldi, A. kennedyi, A. nigricans, A. pictipennis, A. urnaria, Ammophila, Sphecidae, Hymenoptera, wasp, Iowa, USA, neoteny, Paroxenos lugubris

\section{Introduction}

The Strepsiptera is an order of insects comprising obligate endoparasitoids of seven orders of other insects including the Hymenoptera (Kathirithamby 2009). Commonly known as twisted-wing flies, or stylops, stylopization is parasitization by species of Strepsiptera.

Among the Hymenoptera, the reports of stylopization in solitary fossorial, or soil digging, hunting wasps, of the genus Ammophila Kirby appear in Salt (1927a, 1927b, 1931) and Miller et. al. (2009). More recently, Ammophila fernaldi (Murray) and Ammophila pictipennis Walsh were the subjects of a long paper in which the strepsipteran, Paroxenos lugubris Pierce, was found to have infected a significant number of $A$. fernaldi and A. pictipennis (Kathirithamby et al. 2012). Although usually there is one strepsipteran parasitoid per individual insect host, more than one strepsipteran individual per host can occur, a condition known as superparasitism (Kathirithamby 1989, Kathirithamby et al. 2012).

In this paper, I report a female $A$. pictipennis Walsh infected with six extruded strepsipterans, the most I have ever encountered on a single host wasp; and, as far as I know, a number not previously reported for this species (Figures 1-3). Prior to this, the most extruded strepsipterans I have seen on any one A. pictipennis is four (Table 1).

\footnotetext{
${ }^{1}$ Submitted on November 21, 2019. Accepted on December 14, 2019. Last revisions received on December 30, 2019

${ }^{2}$ Sioux City, Iowa, USA. E-mail: garylechner22@gmail.com
}

DOI: 10.9784/LEB7(3)Lechner.01

Electronically available on December 31, 2019. Mailed on December 31, 2019. 


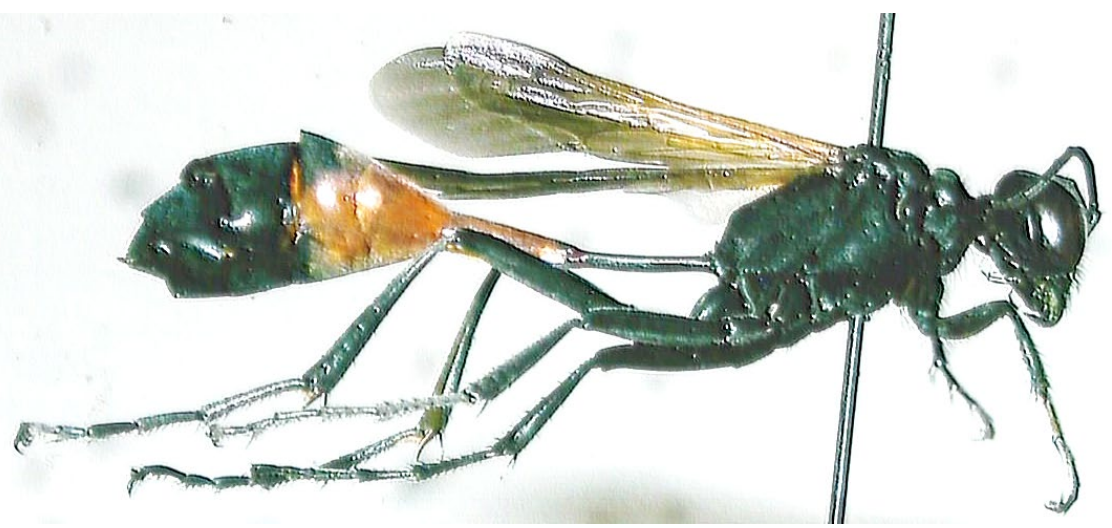

Figure 1. Female Ammophila pictipennis (total length, 22-23 mm) captured on August 17, 2019. This wasp was infected with six protruding strepsipterans.

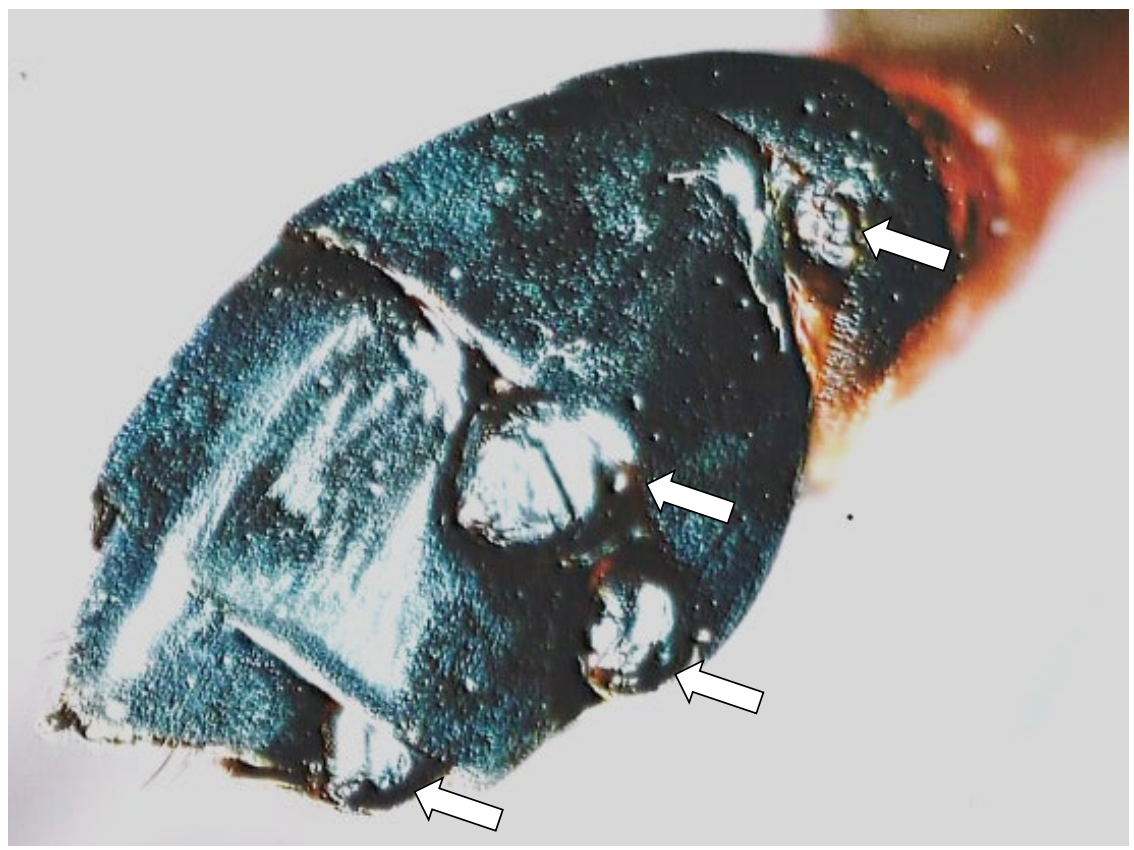

Figure 2. Close-up view of the wasp in Figure 1. Right, dorsolateral aspect of the gaster showing four protruding strepsipterans. 


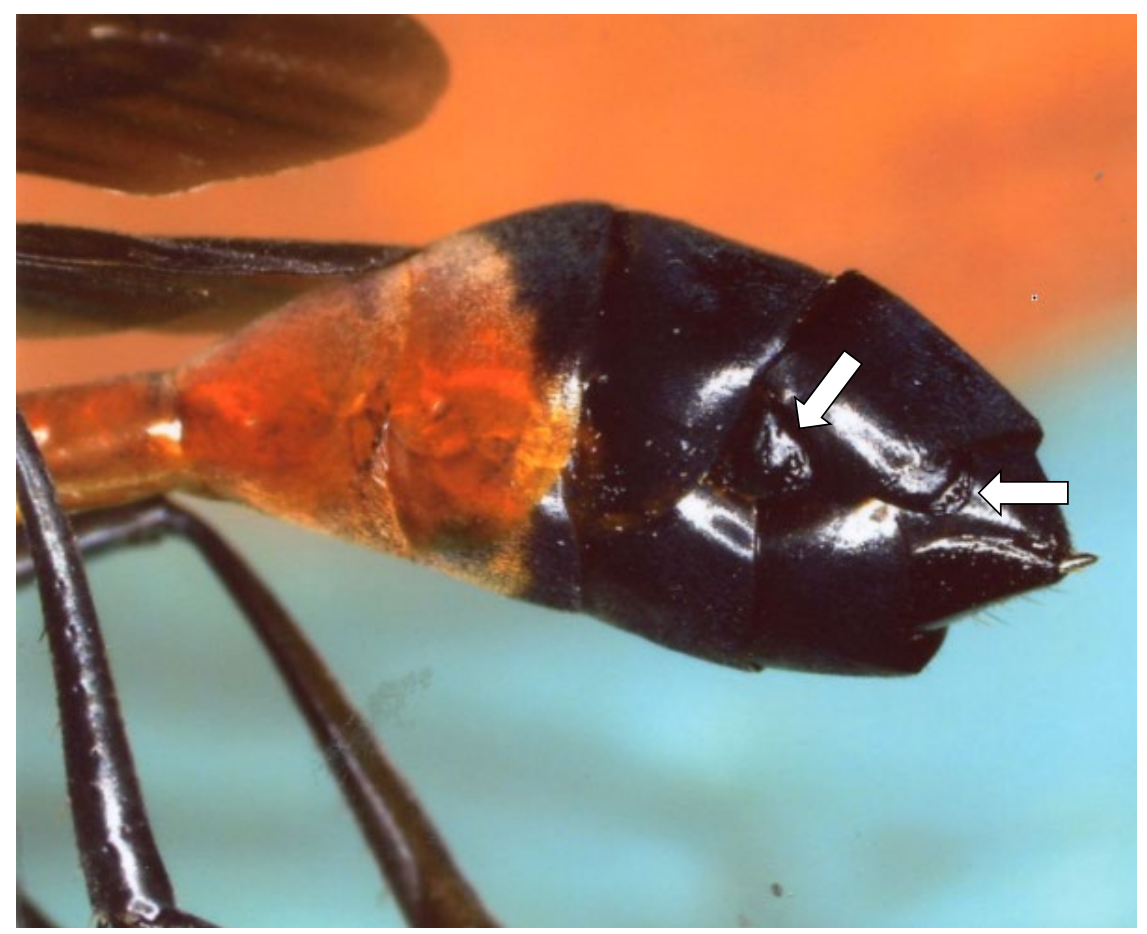

Figure 3. Close-up view of the wasp depicted in Figure 1. Left lateral aspect of the gaster showing two protruding strepsipterans.

\section{Methods}

North High School (Sioux City, Iowa), consists of a complex of buildings, parking lots, and multiple athletic courts and fields located on a somewhat hilly site approximately 20.5 acre $(8.3 \mathrm{ha})$ large. The level areas are mowed quite closely, but on the hillsides the vegetation grows unimpeded except for maintenance pathways and concrete stairs. There is also a 0.5 -acre $(0.2 \mathrm{ha})$ patch north of the buildings sown with native Iowa prairie plants.

I have been visiting this school location every summer since 2005, and Ammophila wasps have been observed here annually, never earlier than 4 June (2010 and 2011) and never later than 30 October (2010). As I have hiked these grounds over the years, whenever possible, typically once per day, approximately one hour per visit, usually between the hours of 1100 and 1500, I have observed Ammophila wasps flying low to the substrate and among the upper stems of the vegetation, but most frequently I have observed them visiting flowers, presumably for nectar. White clover, Trifolium sp. Linnaeus (Fabaceae), and goldenrod, Solidago sp. (Asteraceae), seem to be their favorites. On rare occasions, I have noted these wasps carrying a caterpillar (Lepidoptera) prey or entering a burrow. 
I used a sweep net to capture the Ammophila which were then examined in the field with the unaided eye for the presence of extruded strepsipteran cephalothoraces, cephalothecae or empty male puparia. When fully formed, all these are easily seen protruding from under the terminal edges of the wasps' gastral sclerites. All wasps exhibiting such signs of stylopization were retained for later examination under a dissecting microscope; and, with a few exceptions, almost all wasps appearing to be strepsipteran-free were released. A blanket exception to this procedure was followed in 2008 when all the wasps collected were returned for microscopic examination and subsequent shipment to the University of Oxford (Oxford, England, United Kingdom) where the infecting strepsipterans were identified as Paroxenos lugubris Pierce (Kathirithamby et al. 2012).

The main subject wasp of this paper was collected on 17 August 2019 along the west edge of the previously described native Iowa prairie plot (North High School Prairie Project) located north of the building complex. The coordinates for this collection site were determined to be $\mathrm{N} 42^{\circ} 30.660^{\prime}$ and $\mathrm{W} 096^{\circ} 23.503^{\prime}$ by use of a Garvin Nüvi 350 GPS hand unit. The wasp was captured by sweep net as she flew at approximately head height among the upper stems of grasses. This superparasitized wasp has been deposited as a voucher with Dr. W. J. Pulawski, (California Academy of Sciences, San Francisco, California).

\section{Results}

Table 1 summarizes the findings of stylopization for the years 2008 through 2019.

Table 1. Observed presence or absence of stylopization in wasps of the genus Ammophila Kirby (Hymenoptera: Sphecidae: Ammophilinae) from the grounds of North High School (Sioux City, Iowa, USA; 2008 - 2019). Footnotes under each yearly table contain observations on strepsipteran larvae. Ammophila sp. represents unidentified species of Ammophila.

\begin{tabular}{|c|c|c|c|c|c|c|c|}
\hline \multirow{2}{*}{ Year 2008 $^{1}$} & \multicolumn{7}{|c|}{ Number of Cephalothecae, Cephalothoraces, or } \\
& \multicolumn{7}{|c|}{ Empty Puparia } \\
\hline Species of Wasp & $\mathbf{0}$ & $\mathbf{1}$ & $\mathbf{2}$ & $\mathbf{3}$ & $\mathbf{4}$ & $\mathbf{5}$ & $\mathbf{6}$ \\
\hline Ammophila pictipennis & $29^{2}$ & $11^{3}$ & $3^{4}$ & 5 & 2 & 0 & 0 \\
\hline Ammophila fernaldi & $80^{5}$ & $34^{6}$ & $14^{7}$ & $3^{8}$ & 4 & 1 & 0 \\
\hline
\end{tabular}

1. All wasps collected in 2008 were shipped to the University of Oxford in Oxford, United Kingdom and were the basis for Kathirithamby et al. (2012).

2. Seven wasps in this category also bore strepsipteran larvae.

3. Two wasps in this category also bore strepsipteran larvae: one wasp with 60 or more larvae; the second wasp over 100 larvae.

4. One wasp in this category also bore eight strepsipteran larvae.

5. Seventeen wasps in this category also bore strepsipteran larvae.

6. Six wasps in this category also bore strepsipteran larvae $(n=1,3,12,30,>50$, or $>55)$.

7. Two wasps in this category also bore strepsipteran larvae: one wasp with three larvae; the second wasp with seven larvae.

8. One wasp in this category also bore two strepsipteran larvae. 


\begin{tabular}{|c|c|c|c|c|c|c|c|}
\hline \multirow{2}{*}{ Year 2009 } & \multicolumn{7}{|c|}{ Number of Cephalothecae, Cephalothoraces, or } \\
Empty Puparia \\
\hline Species of Wasp & $\mathbf{0}$ & $\mathbf{1}$ & $\mathbf{2}$ & $\mathbf{3}$ & $\mathbf{4}$ & $\mathbf{5}$ & $\mathbf{6}$ \\
\hline Ammophila fernaldi & 3 & 2 & 0 & 0 & 0 & 0 & 0 \\
\hline Ammophila sp. & 43 & 7 & 4 & 1 & 0 & 0 & 0 \\
\hline
\end{tabular}

\begin{tabular}{|c|c|c|c|c|c|c|c|}
\hline \multirow{2}{*}{ Year 2010} & \multicolumn{7}{|c|}{ Number of Cephalothecae, Cephalothoraces, or } \\
& \multicolumn{7}{|c|}{ Empty Puparia } \\
\hline Species of Wasp & $\mathbf{0}$ & $\mathbf{1}$ & $\mathbf{2}$ & $\mathbf{3}$ & $\mathbf{4}$ & $\mathbf{5}$ & $\mathbf{6}$ \\
\hline Ammophila pictipennis & 24 & $2^{1}$ & 0 & 0 & 0 & 0 & 0 \\
\hline Ammophila fernaldi & 5 & 0 & 0 & 0 & 0 & 0 & 0 \\
\hline Ammophila sp. & 52 & 0 & 0 & 0 & 0 & 0 & 0 \\
\hline
\end{tabular}

1. One wasp in this category also had 29 larvae (Figure 4, see page 154).

\begin{tabular}{|c|c|c|c|c|c|c|c|}
\hline Year 2011 & \multicolumn{7}{|c|}{ Number of Cephalothecae, Cephalothoraces, or } \\
Empty Puparia & $\mathbf{5}$ & $\mathbf{6}$ \\
\hline Species of Wasp & $\mathbf{0}$ & $\mathbf{1}$ & $\mathbf{2}$ & $\mathbf{3}$ & $\mathbf{4}$ & $\mathbf{5}$ & 0 \\
\hline Ammophila pictipennis & 32 & 0 & 2 & 1 & 0 & 0 & 0 \\
\hline Ammophila fernaldi & 34 & 4 & 2 & 1 & 0 & 0 & 0 \\
\hline Ammophila sp. & 9 & 1 & 1 & 0 & 0 & 0 & 0 \\
\hline
\end{tabular}

\begin{tabular}{|c|c|c|c|c|c|c|c|}
\hline \multirow{2}{*}{ Year 2012 } & \multicolumn{7}{|c|}{ Number of Cephalothecae, Cephalothoraces, or } \\
Empty Puparia & $\mathbf{3}$ & $\mathbf{4}$ & $\mathbf{5}$ & $\mathbf{6}$ \\
\hline Species of Wasp & $\mathbf{0}$ & $\mathbf{1}$ & $\mathbf{2}$ & $\mathbf{3}$ & 0 & 0 \\
\hline Ammophila pictipennis & 19 & 0 & 0 & 0 & 0 & 0 & 0 \\
\hline Ammophila fernaldi & 3 & 0 & 0 & 0 & 0 & 0 & 0 \\
\hline
\end{tabular}

\begin{tabular}{|c|c|c|c|c|c|c|c|}
\hline \multirow{2}{*}{ Year 2013 } & \multicolumn{7}{|c|}{ Number of Cephalothecae, Cephalothoraces, or } \\
& \multicolumn{7}{|c|}{ Empty Puparia } \\
\hline Species of Wasp & $\mathbf{0}$ & $\mathbf{1}$ & $\mathbf{2}$ & $\mathbf{3}$ & $\mathbf{4}$ & $\mathbf{5}$ & $\mathbf{6}$ \\
\hline Ammophila pictipennis & 4 & 0 & 0 & 0 & 0 & 0 & 0 \\
\hline Ammophila fernaldi & 1 & 0 & 0 & 0 & 0 & 0 & 0 \\
\hline
\end{tabular}

\begin{tabular}{|c|c|c|c|c|c|c|c|}
\hline Year 2014 & \multicolumn{7}{|c|}{$\begin{array}{c}\text { Number of Cephalothecae, Cephalothoraces, or } \\
\text { Empty Puparia }\end{array}$} \\
\hline Species of Wasp & $\mathbf{0}$ & $\mathbf{1}$ & $\mathbf{2}$ & $\mathbf{3}$ & $\mathbf{4}$ & $\mathbf{5}$ & $\mathbf{6}$ \\
\hline Ammophila pictipennis & 15 & 0 & 0 & 0 & 0 & 0 & 0 \\
\hline Ammophila fernaldi & 13 & 1 & 0 & 0 & 0 & 0 & 0 \\
\hline Ammophila cleopatra & $1^{1}$ & 0 & 0 & 0 & 0 & 0 & 0 \\
\hline Ammophila sp. & 1 & 0 & 0 & 0 & 0 & 0 & 0 \\
\hline
\end{tabular}

1. This wasp was identified by A.S. Menke, Ammophila Research Institute, Bisbee, Arizona and donated to this research unit (Figure 5, see page 155). 


\begin{tabular}{|c|c|c|c|c|c|c|c|}
\hline Year 2015 & \multicolumn{7}{|c|}{ Number of Cephalothecae, Cephalothoraces, or } \\
Empty Puparia & $\mathbf{3}$ & $\mathbf{5}$ & $\mathbf{6}$ \\
\hline Species of Wasp & $\mathbf{0}$ & $\mathbf{1}$ & $\mathbf{2}$ & $\mathbf{3}$ & $\mathbf{4}$ & 0 \\
\hline Ammophila pictipennis & 78 & 1 & 1 & 0 & 0 & 0 & 0 \\
\hline Ammophila fernaldi & 28 & $4^{1}$ & 2 & 0 & 0 & 0 & 0 \\
\hline Ammophila urnaria & 6 & 0 & 0 & 0 & 0 & 0 & 0 \\
\hline Ammophila nigricans & $2^{2}$ & 0 & 0 & 0 & 0 & 0 & 0 \\
\hline Ammophila sp. & 4 & 0 & 0 & 0 & 0 & 0 & 0 \\
\hline
\end{tabular}

1. One wasp in this category had a strepsipteran larva on a wing.

2. These wasps were identified by A. S. Menke, Ammophila Research Institute, Bisbee, Arizona. They were donated to this research unit.

\begin{tabular}{|c|c|c|c|c|c|c|c|}
\hline \multirow{2}{*}{ Year 2016} & \multicolumn{7}{|c|}{ Number of Cephalothecae, Cephalothoraces, or } \\
& \multicolumn{7}{|c|}{ Empty Puparia } \\
\hline Species of Wasp & $\mathbf{0}$ & $\mathbf{1}$ & $\mathbf{2}$ & $\mathbf{3}$ & $\mathbf{4}$ & $\mathbf{5}$ & $\mathbf{6}$ \\
\hline Ammophila pictipennis & $58^{1}$ & $3^{2}$ & $4^{3}$ & 2 & 0 & 0 & 0 \\
\hline Ammophila fernaldi & 17 & $1^{4}$ & 0 & 0 & 0 & 0 & 0 \\
\hline Ammophila urnaria & 3 & 0 & 0 & 0 & 0 & 0 & 0 \\
\hline Ammophila kennedyi & $1^{5}$ & 0 & 0 & 0 & 0 & 0 & 0 \\
\hline Ammophila sp. & 6 & 0 & 0 & 0 & 0 & 0 & 0 \\
\hline
\end{tabular}

1. One wasp in this category was a male with previously unreported silver setae on the thoracic sutures/sulci (Figures 6 and 7, see pages 155 and 156, respectively).

2. One wasp in this category had a strepsipteran larva on a wing.

3. One wasp in this category had two strepsipteran larvae: one on a leg, the other on the gaster.

4. This wasp had one strepsipteran larva on a wing.

5. This wasp was identified by A .S. Menke, Ammophila Research Institute, Bisbee, Arizona. The wasp was donated to this research unit (Figure 8, see page 156).

\begin{tabular}{|c|c|c|c|c|c|c|c|}
\hline \multirow{2}{*}{ Year 2017 } & \multicolumn{7}{|c|}{ Number of Cephalothecae, Cephalothoraces, or } \\
Empty Puparia & $\mathbf{6}$ \\
\hline Species of Wasp & $\mathbf{0}$ & $\mathbf{1}$ & $\mathbf{2}$ & $\mathbf{3}$ & $\mathbf{4}$ & $\mathbf{5}$ & $\mathbf{6}$ \\
\hline Ammophila pictipennis & 50 & 3 & 4 & 0 & 0 & 0 & 0 \\
\hline Ammophila fernaldi & 3 & 0 & 0 & 0 & 0 & 0 & 0 \\
\hline Ammophila sp. & 13 & 0 & 0 & 0 & 0 & 0 & 0 \\
\hline
\end{tabular}

\begin{tabular}{|c|c|c|c|c|c|c|c|}
\hline \multirow{2}{*}{ Year 2018} & \multicolumn{7}{|c|}{ Number of Cephalothecae, Cephalothoraces, or } \\
Empty Puparia \\
\hline Species of Wasp & $\mathbf{0}$ & $\mathbf{1}$ & $\mathbf{2}$ & $\mathbf{3}$ & $\mathbf{4}$ & $\mathbf{5}$ & $\mathbf{6}$ \\
\hline Ammophila pictipennis & 61 & 1 & 0 & 0 & 0 & 0 & 0 \\
\hline Ammophila fernaldi & 16 & 2 & 0 & 0 & 0 & 0 & 0 \\
\hline Ammophila urnaria & 4 & 0 & 0 & 0 & 0 & 0 & 0 \\
\hline Ammophila nigricans & $1^{1}$ & 0 & 0 & 0 & 0 & 0 & 0 \\
\hline
\end{tabular}

1. This wasp was identified by A. S. Menke, Ammophila Research Institute, Bisbee, Arizona. The wasp was donated to this research unit. 


\begin{tabular}{|c|c|c|c|c|c|c|c|}
\hline \multirow{2}{*}{ Year 2019} & \multicolumn{7}{|c|}{ Number of Cephalothecae, Cephalothoraces, or } \\
& \multicolumn{7}{|c|}{ Empty Puparia } \\
\hline Species of Wasp & $\mathbf{0}$ & $\mathbf{1}$ & $\mathbf{2}$ & $\mathbf{3}$ & $\mathbf{4}$ & $\mathbf{5}$ & $\mathbf{6}$ \\
\hline Ammophila pictipennis & $52^{1}$ & $7^{2}$ & $2^{3}$ & 0 & 1 & 0 & $1^{4}$ \\
\hline Ammophila fernaldi & 38 & $2^{5}$ & 0 & 0 & 0 & 0 & 0 \\
\hline Ammophila urnaria & 3 & 0 & 0 & 0 & 0 & 0 & 0 \\
\hline Ammophila sp. & 24 & 0 & 0 & 0 & 0 & 0 & 0 \\
\hline
\end{tabular}

1. One wasp in this category had larvae on wings $(n=2)$.

2. Three wasps in this category also bore larvae exteriorly $(n=2, n=6$, and $n=7)$. A fourth wasp in this category bore 61 exterior larvae; and when this wasp was dissected, an additional 286 larvae were counted from the body of the female strepsipteran. Counting ceased at this point, but other larvae were still visible including the undeveloped larvae too numerous to count (Figures 9 and 10 , see page 157).

3. One wasp in this category bore over 135 larvae (Figure 11, see page 158). This wasp was donated to Dr. Jeyaraney Kathirithamby, University of Oxford (Oxford, England, United Kingdom).

4. Figures 1,2 and 3 .

5. Both these wasps bore larvae on wings and $\operatorname{leg}(n=3$ and $n=5)$. An additional 6 - 7 larvae were extracted from the brood canal opening of one of the cephalothoraces.

From the summer of 2008 through the summer of 2019 (inclusive, twelve years), a total of 984 wasps of the genus Ammophila Kirby were collected and examined for the presence of externally visible signs of stylopization - extruded strepsipteran cephalothoraces (females), cephalothecae (males), or empty puparia (males). Of these 984 wasps, 147 bore one or more extruded strepsipterans yielding a stylopization rate of $14.9 \%$. Of these 147 stylopsized wasps, 61 were superparasitized with two or more strepsipterans.

It is possible that the stylopization rate could be higher since some wasps might have been infected but would have been overlooked if the strepsipterans were not fully developed and/or not yet extruded.

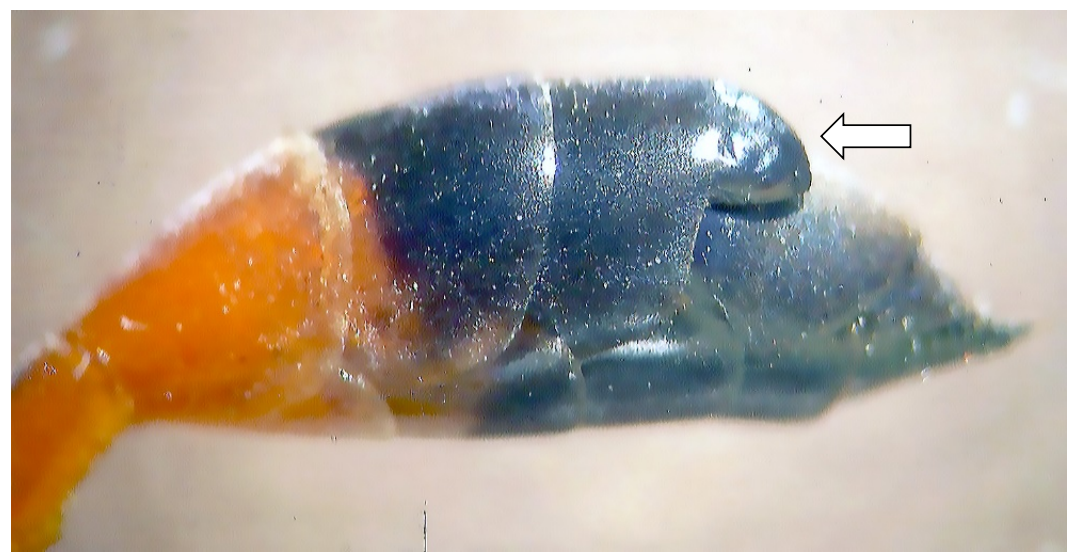

Figure 4. Close-up view of the left side of the gaster of a female Ammophila pictipennis captured on October 10, 2010 showing one protruding strepsipteran. 


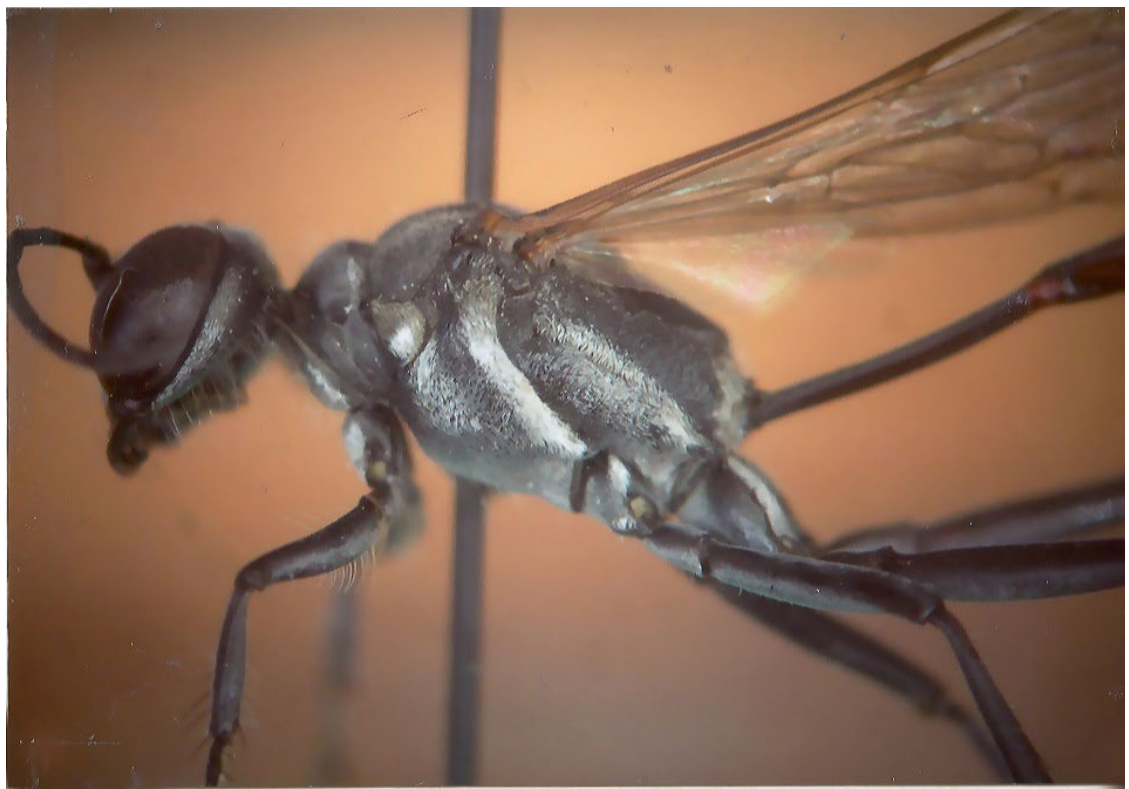

Figure 5. Female Ammophila cleopatra (total length, approximately $19 \mathrm{~mm}$ ) captured on July 19, 2014. This wasp was identified by A.S. Menke, Ammophila Research Institute, Bisbee, Arizona and donated to this research unit.

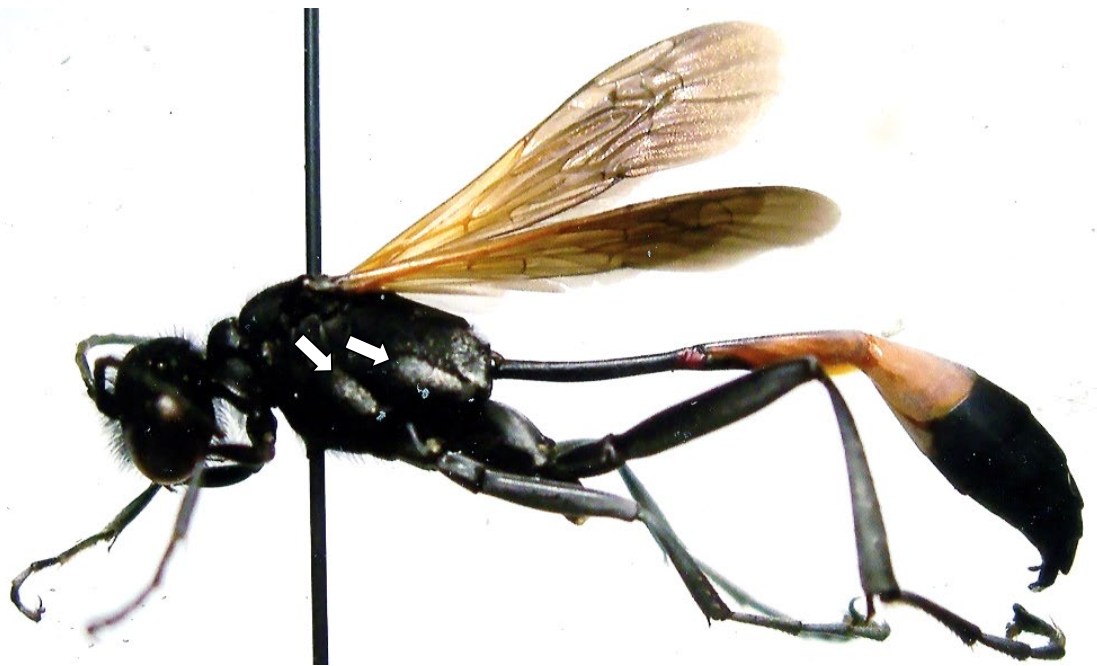

Figure 6. Male Ammophila pictipennis (total length, approximately $23 \mathrm{~mm}$ ) captured on August 10, 2016. This wasp bears previously unreported patches of silver setae (arrows). This wasp was identified by A.S. Menke, Ammophila Research Institute, Bisbee, Arizona and donated to this research unit. 


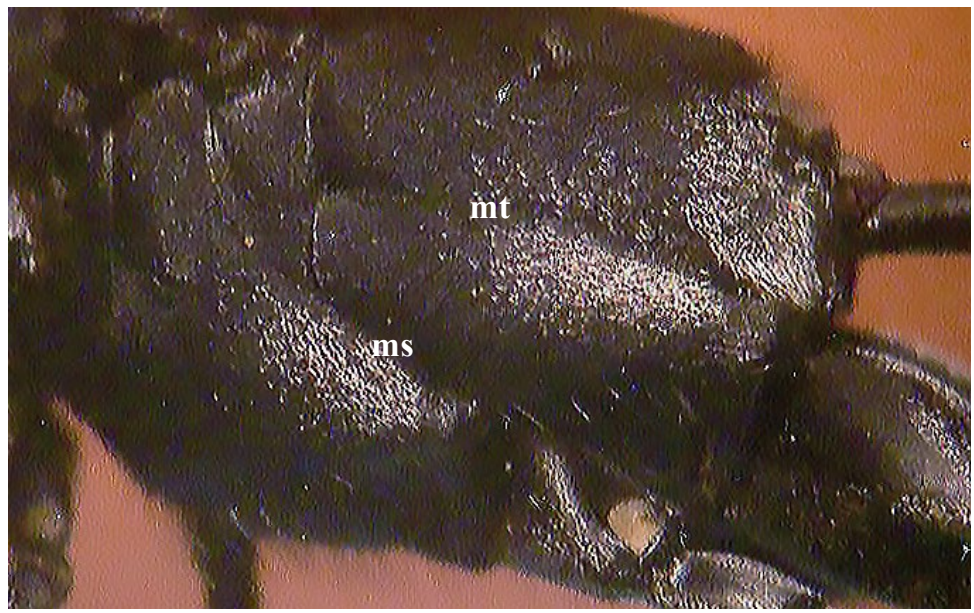

Figure 7. A closer view of the wasp shown in Figure 6. Note the patches of silver setae just below the mesopleural suture (ms) and the metapleural sulcus (mt). As far as it is known, this condition has been found only in the specimens from Sioux City, Iowa (A. S. Menke, personal communication) and it is infrequent (i.e., only 11 out of 58 male A. pectipennis examined during 2016-2019 showed this phenotype).

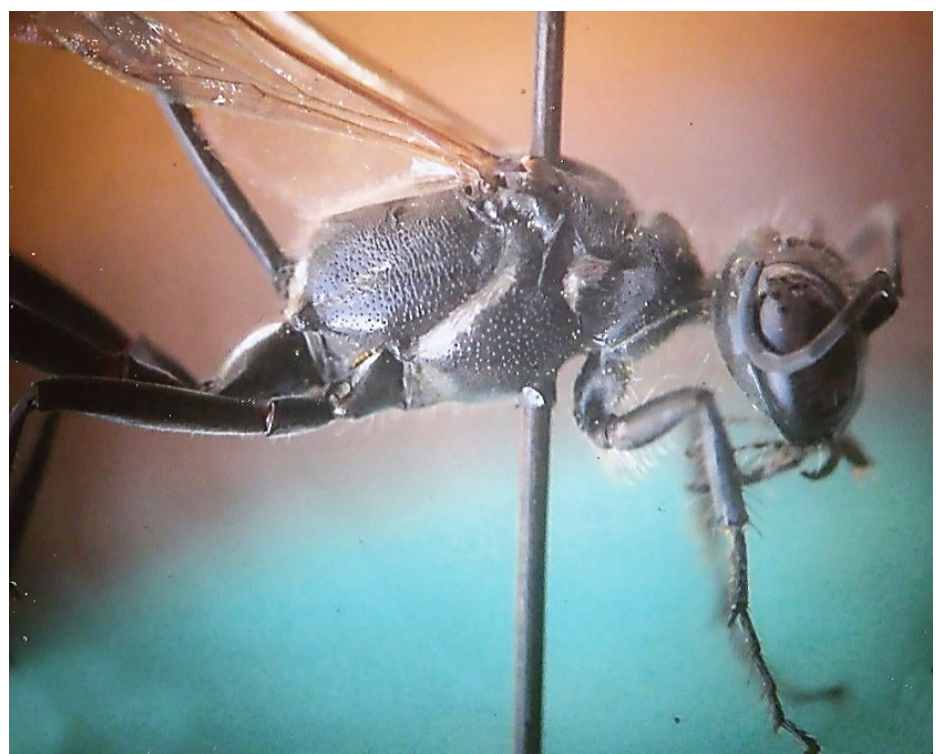

Figure 8. Female Ammophila kennedyi (total length, approximately $16 \mathrm{~mm}$ ) captured on October 1, 2016. This wasp was identified by A.S. Menke, Ammophila Research Institute, Bisbee, Arizona and donated to this research unit. 

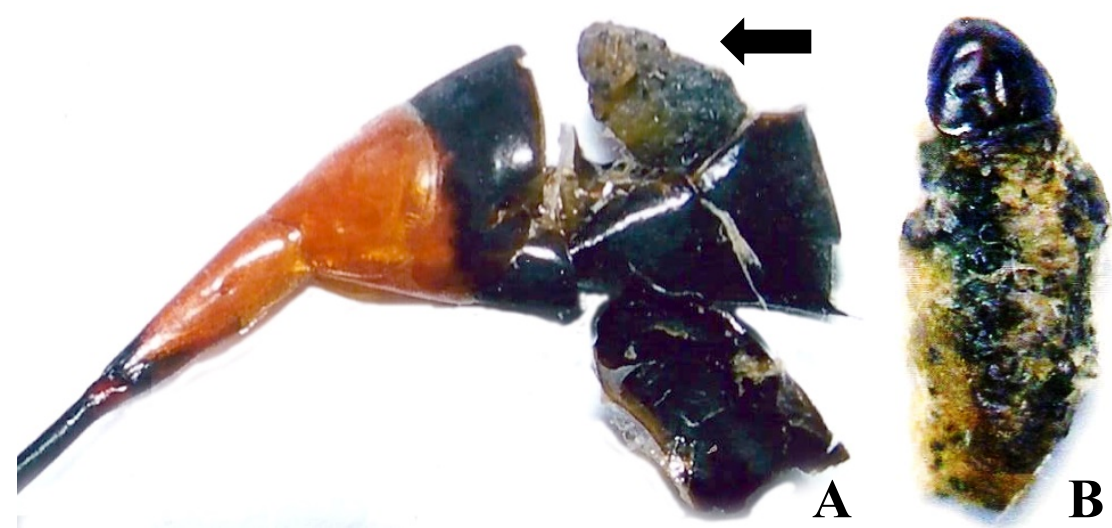

Figure 9. A. Neotenic, or adult with juvenile body, female strepsipteran (arrow) removed from a female Ammophila pictipennis wasp collected on October 6, 2019. This was the only strepsipteran noted protruding from this wasp. Upon dissection, 286 first instar strepsipteran larvae were collected in and around this neotenic female before counting ceased. An additional 61 first instar larvae had been previously collected from the exterior of the wasp. B. Enlarged image of neotenic female strepsipteran out of the wasp (approximately $4 \mathrm{~mm}$ long).

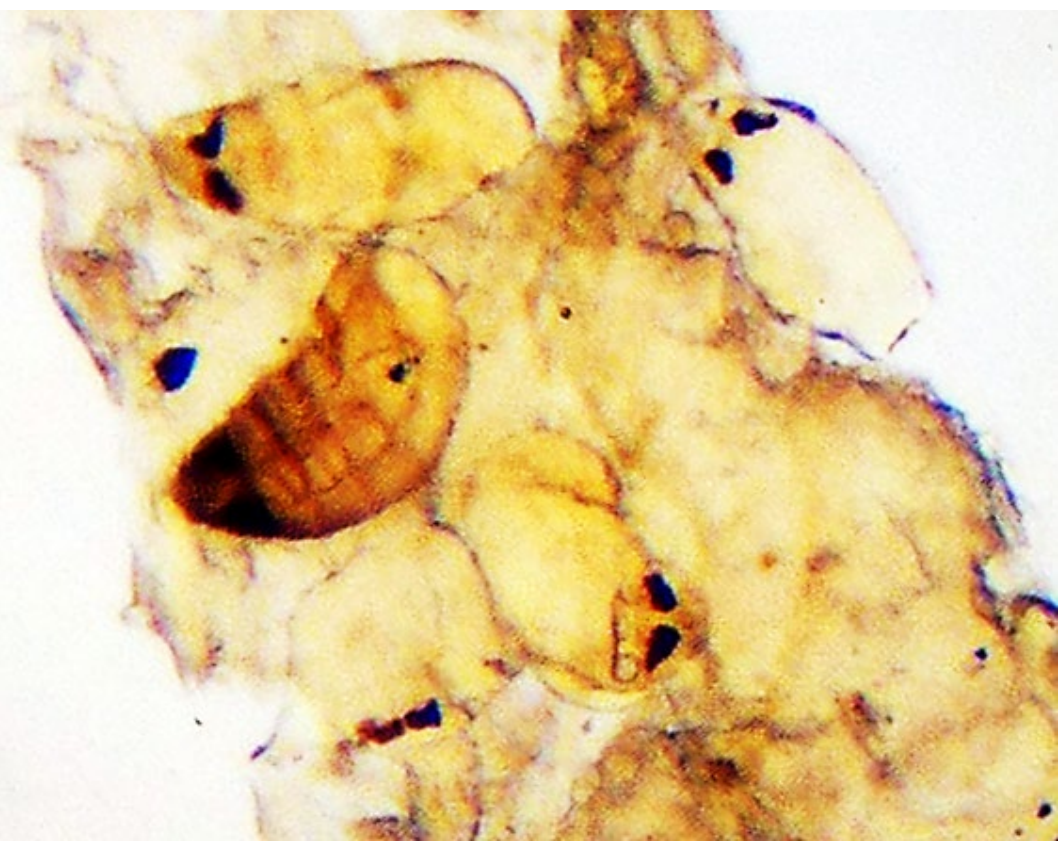

Figure 10. Group of not fully developed first instar strepsipterans recovered from the neotenic female strepsipteran shown in Figure 9B. 


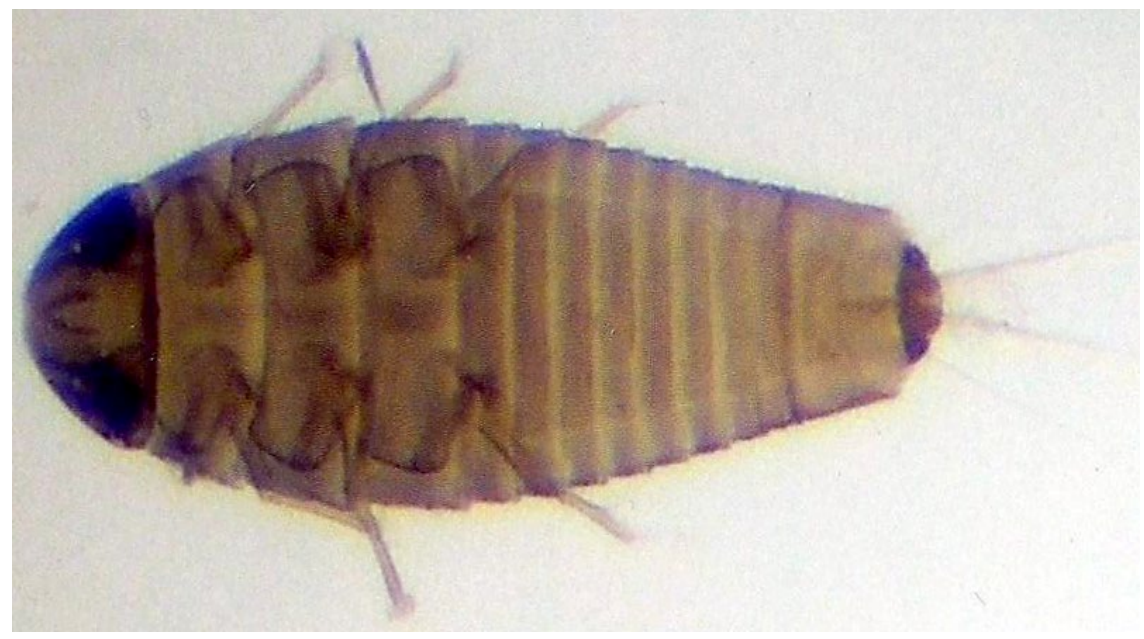

Figure 11. First instar strepsipteran larva (estimated length, 250 microns) collected from the exterior of a female Ammophila pictipennis wasp captured on September 7, 2019. Over 135 first instar larvae were collected from the wasp.

\section{Acknowledgements}

Many thanks to Ms. Cindy Opitz (Collections Manager, Museum of Natural History, University of Iowa), Dr. Andrew Forbes (Associate Professor, Department of Biology, University of Iowa), and Dr. Daniel Soluk (Professor, University of South Dakota), for their gracious assistance with microphotography of the subject wasp of this paper. In addition, I am grateful to Arnold S. Menke (Ammophila Research Institute, Bisbee, Arizona), for the many Ammophila identifications and information on this genus he has provided me over the years. Also, thanks to Dr. Jeyaraney Kathirithamby (University of Oxford, England, United Kingdom) for answering many questions I had.

\section{Literature Cited}

Kathirithamby, J. 1989. A review of the Order Strepsiptera. Systematic Entomology 14:41-92. https://doi.org/10.1111/j.1365-3113.1989.tb00265.x

Kathirithamby, J. 2009. Host parasitoid associations in Strepsiptera. Annual Review of Entomology 54:227-249. https://doi.org/10.1146/annurev.ento.54.110807.090525

Kathirithamby, J, G. K. Lechner, D. P. McMahon, A. L. Bryson, and J. S. Johnston. 2012. A free ride and a free lunch: stylopization in the solitary hunting wasp, Ammophila fernaldi Murray and A. pictipennis (Walsh) (Hymenoptera: Sphecidae) by Paroxenos lugubris Pierce (Strepsiptera). Proceedings of the Entomological Society of Washington 114(2):464-475.

Miller, R. S., A. M. Pearce, and K. M. O'Neill. 2009. Prevalence of stylopization of Sphex ichneumoneus (L.) (Hymenoptera: Sphecidae) by Paroxenos westwoodi (Templeton) (Strepsiptera: Xenidae). Psyche 2009:1-4. https://doi.org/10.1155/2009/690125

Salt, G. 1927a. The effects of stylopization on aculeate Hymenoptera. The Journal of Experimental Zoology 48(1):223-331. https://doi.org/10.1002/jez.1400480107

Salt, G. 1927b. Notes on the Strepsiptera and their hymenopterous hosts. Psyche 34:182-192. https://doi.org/10.1155/1927/25470

Salt, G. 1931. A further study of the effects of stylopization on wasps. Journal of Experimental Zoology 59(1):133-166. https://doi.org/10.1002/jez.1400590107 